\title{
DEVELOPING NONSPECIAL TEACHERS MOTIVATION IN LEARNING ENGLISH
}

\section{Elvira Tursunnazarova \\ Lecturer of the Department of Methods of Teaching Languages, Regional Center for Retraining and Advanced Training of Public Education Workers at the Navai State Pedagogical Institute, Uzbekistan}

Annotation: the article discusses ways to increase the motivation of students of English non-specialists in the study of a foreign language.

Key words: motivation, foreign language, higher education institution, students .

The word "motive" is often used to refer to such psychological phenomena as desire, desire, intention, fear, and others, which are reflected in a person in the form of readiness for activity leading to a specific goal [3, p. 71]. Human activity is guided by a multitude of motives, the totality and internal process of interaction of which is calledmotivation.

Motivation is the motivation to work with a set of different motifs, creating a specific status 1 I confirm the identity, which is defined yaet on how actively and how oriented people act in a certain situation [3, p. 71]. When it comes to student motivation, we are talking about the desire, the desire of students to participate in the learning process.

The problem of motivation in learning a foreign language, according to $\mathrm{M}$. Rost [2], is important. And in reality, problems in motivation arise at least because:

1) there are no great features to enable students in the environment of communication in a foreign language;

2) there are not enough speakers who can communicate;

3) in society there was no persistent belief in the need to study foreign languages. For other reasons, the student should have just called extraordinary hydrochloric internal and external motivation to learn a foreign language.

No wonder K. Ames quotes T. Bela's quotation: "There are three things about which you must remember in education. The first thing is motivation. The 
second thing is motivation. The third is motivation "[ 1$]$.

Motivation is defined as targeting. This orientation may be positive, negative or ambivalent (dual).

It can be said that motivation provides a source of energy that does not set the responsibility for why the learner decided to make an effort, like for a long time he is ready to support the activity, how persistently he will pursue the goal, how much he feels connected with the activity [2]. Thus, maintaining this source of positive energy is of great importance for the ultimate success in learning a foreign language. All that a foreign language teacher does in class, ultimately has two goals. One of them is the further development of language skills, and the other is the creation of motivation to continue learning.

Speaking about the teacher, it should be mentioned that the learners show more motivation to study the subject, if they like the teacher, than with those who do not like. The basis of feature 1 yubogo successful teacher is his 1 I confirm the identity. The teacher should be an interesting, attractive, confident and optimistic person with many creativeideas. He should be able not only to transfer knowledge, but also to communicate with the student and maintain a positive relationship with them.

Another point is the teacher's enthusiasm. If he is big enthusiastically gives information on the topic, students will be more inclined to believe that the topic is important to them. That is the teacher's enthusiasm can also motivate learners .

And, of course, there is no doubt that the teacher should be a professional in their field. He must constantly develop his language skills, improve himself: communicate with native speakers, translate complex texts, listen to foreign songs in order to follow trends in the language.

Learning content in the teaching of a foreign language should be relevant and meet the life needs of the student .

In addition, positive verbal approval, encouragement and praise can greatly affect the motivation of students . Praise for the effort may help them develop selfconfidence.Assessing the response of the student, we try to evaluate not only the knowledge and skills, but also the progress spent time.

Public speaking has a big impact on motivation. students. Fear of Public Speaking I S common phobia her most yudey 1 . Our students, communicating in small groups, work out the practice of public speaking, which helps them to get 
better and increase their self-esteem. The environment is another key element of student motivation.

First of all, the environment should be accessible. The teacher can then take three basic principles rukovodstva- solid, fair, Drew Divine - the teacher must create a favorable atmosphere to the projection, being solid, consistent, fair and affordable.

Project work when learning a foreign language can be a factor that will create a positive emotional and cognitive environment. Forming small project groups that include both strong students and those with an average level of training, we include the work of all students.

Specially developed system of exercises, performing which

students would feel the result of their work, also leads to increased motivation to learn a foreign language at a university.

In the study of a new 1 eksiki on such exercises can be used as a crossword puzzle, drawing on the history of the picture.

For example, the game "Find the words." A grid of cells is given, a letter of the alphabet is written in each cell. Among the set of letters hidden words on the theme "ecology".

Students need to find the words in the list and translate. Instruction:

Words can be written forward, backward, vertically; horizontally and, or diagonally. The words are all connected with the theme "ecology".

You must search for the following words, mark them on the grid and write a translation aside so that you understand their meanings.

Crossword can be used not only as an individual figure Nosta training, but also as a number of projective 1 . The group is divided into 2 groups (A and $B$ ).

A crossword puzzle is made using the words on the topic, then all words of the word cross are divided equally; 2 blank forms, one of them is filled with one part of the words, the other with the second, so that they complement each other. One form given to group A, the other Group B To fill the crossword eobho Mr. Dimo participated in both groups: group A group explains ne The value of the words to torye available in its form, and then change the group.

Instruction:

Group work A and B. You are group A. 
Some of the words in this crossword are missing. Group B knows what they are. Group B also has some words that are missing in their crossword.

Use this one at a time to ask each other the meaning of the missing word.

Using such a method as drawing up a story from a picture

It is also used to study the new L ek Shiki. This method develops voob expressions of students and allows students to show their knowledge gained in other lessons or liter ary experience.

Or, for example, the game "Chain", a game of drawing up collective races , tolerantly accentuated by subject, content and meaning. AT During the game, each of the students comes up (offer) one vomu key words that should enter in to the 1 selectivity story, and writes it on a separate card. Further participants constitute sequentially before ldix keyword and announce it aloud.

The story is made up along the chain, in l ogic interconnection of the socalled sentences. After that, as everyone says, cards with keywords are collected and participants (optional) have the opportunity to restore the verbal-text series of tolerant-communicative plot.

So, to summarize all of the above, we can offer several practical ways to increase the motivation of students in learning a foreign language.

- Give trainers the choice. For example, let them choose the type tasks that they do, the form - oral or written, retelling text or dialogue on the learned text.

- Define goals and criteria. Students feel uncomfortable in group, performing the task, if there are no clearly defined goals, and they are not familiar with the criteria for your assessment of their work. Students want and need know what is expected of them to stay motivated. At the beginning of the year Define clear goals, rules and your expectations from students so that there is no confusion during the training period and the sessional period.

- Create a favorable environment (environment). Of course, students must understand that there are certain consequences of their actions. for inaction. However, studentsare more motivated by positive attitudes, praise, approval, undesirable threats and what will happen if actions and actions are not met. When the teach of Tell create a safe, blahgopriyatnuyu environment for students, confirming their faith in the ability to learn, and do not explain the consequences, students are much more likely get and keep motivation to do the job. 
- Offer versatile work. Not all learners will respond in the classroom in the same way. For some practical 1 uchshe experience. Others may yubit 1 read a book or work in groups. For In order to maintain the motivation of all students, rotate your exercises so that they are at different preferences focused on the things that they 1 yubyat most. This will help learner to continue working together and stay focused.

- Use positive competition. Competition in the audience is not always a negative phenomenon, in some cases it can motivate students to try and work to succeed. The friendly spirit of perseverance in your group can be awakened through group role-playing games related to the use of the material being studied, through micro conferences on written regional geographic essays with the preparation of presentations .

- Offer rewards. Each 1 th bit to receive awards, and The possibility of the student to earn their yavlyaets I'm an excellent source of motive tion. Things like tea drinking, watching films in a foreign language, or just praise and a compliment in a lesson can make students learn to work and really strive to achieve goals. Learn 1 I confirm the identityand the needs of your trainees to determine the appropriate rewards for your group.

- Give the learner a sense of responsibility. Say when polling Retell the text on the topic, listen to the strongest students and mean that they are responsible for receiving the retelling from the rest. This kind Responsibility is a great way to coordinate the community and increase students' sense of motivation.

- Allow the student to work together m.

- Although not all trainees will be full of entuviama, having the opportunity to work in groups, many will find it sufficiently positive to try to solve problems together, do experiments and work on projects with other student s. Social interaction can make them motivate each other to reach a goal. Trainers should ensure that groups are balanced and fair .

- Be an enthusiast of your work. One liter uchshih ways to your students stayed motivated - to share your enthusiasm. When you yourself are passionate about the process of working and learning, students will subscribe your energy.

- Know as much as you can about your learner. Getting to know Student E - it is something more than just memorizing the Maintenance of 
their names and surnames.

Students should know that their teacher expresses genuine interest in them and cares about them and their successes. Take a break at the L projections or during change, to ask them about the family, for a hobby. When students themselves znachimymi- chuvst exist it creates a safer learning environment th and motivates them to work is, they feel that they know and respect both individual 1 I confirm the identity. The fact that you know about the student more than just names and IU a few other advantages, namely, it allows us to connect in the classroom learning material and items that are interested or studying ispy ary 1 hoist on experience.

- Help the learner find intrinsic motivation. They should be able to generate their own motivation.

- Set high, but achievable goals. Trainees should strive to a certain level of mastering a foreign language, and should be sure that with your help you will reach this level.

- Provide feedback and offer learner opportunities for improvements.

- Track progress. The learner may be difficult to see how they went far in the study of the subject, especially if the subject is not easy. Therefore, it is necessary to verbally voice the progress of each student, showing him what he has achieved.

It is thought, thanks to these practical suggestions, teachers a foreign language will be able to increase in the future and is already increasing in the present motivation ofstudents in learning a foreign language.

\section{LIST OF USED LITERATURE:}

1. Carol A. Ames . What teachers need to know [Electronic resource] // http://www.unco.edu/cebs/psychology/kevinpugh/motivation_project/resources/ ames90.pdf.

2. Michael Rost . Generating Student Motivation. Michael Rost Series Editor of World View // www.longman.com / worldview .

3. Rebrin YI Quality management: studies. allowance. - Taganrog: Publishing house of TSURE, 2004. 